\title{
THE FIGHT AGAINST THE "ISLAMIC STATE" IN SYRIA: TOWARDS THE MODIFICATION OF THE RIGHT TO SELF-DEFENCE?
}

\author{
IRENE COUZIGOU \\ irene.couzigou@abdn.ac.uk \\ Law School, \\ University of Aberdeen
}

\begin{abstract}
This article analyses whether the military operation against the "Islamic State" in Syria led to a modification of the right to self-defence in customary international law. It outlines the arguments presented by some States in favour of a right to self-defence against the IS as a non-State actor. It also explains that, in contradiction with the traditional temporal understanding of the right to self-defence, some of the States intervening in Syria assert a right to react to imminent armed attacks or even to a simple threat of armed attacks committed by the IS. This article shows that there is limited international acceptance of a broad right to self-defence as a justification for the military involvement in Syria. It concludes that neither a right to self-defence against a non-State actor, nor a right to self-defence in reaction to potential future attacks, has crystallised in customary international law. However it acknowledges that the fight directed against the IS in Syria constitutes another step towards the emergence of a customary right to self-defence against non-State actors in response to current or future armed attacks.
\end{abstract}

Keywords: right to self-defence; right to anticipatory self-defence;

right to pre-emptive self-defence; State; non-State actor; "Islamic State"

How to cite: Couzigou, Irène (2017), "The Fight against the 'Islamic State' in Syria:

Towards the Modification of the Right to Self-Defence?," Geopolitics, History, and

International Relations 9(2): 80-106.

Received 30 April $2016 \cdot$ Received in revised form 15 December 2016

Accepted 16 December 2016 • Available online 28 December 2016 


\section{Introduction}

Since the outbreak of the Syrian civil war in 2011, organised networks have spread across borders in the Middle-East, overtaking cities. The most famous of these is the "Islamic State of Iraq and the Levant" ("ISIL"), more commonly known as the "Islamic State" (IS). ${ }^{1}$ The jihadist group announced the establishment of a Caliphate or "Islamic State," claiming exclusive political and theological authority over the world's Muslims. Militants of the IS now control wide portions of territory in Iraq and Syria as well as a territory in Libya. ${ }^{2}$ The IS has killed and injured thousands of people and the IS-related violence has led to the displacement of over a million people. Atrocities committed or inspired by the IS have extended to the Middle-East, Africa, Europe, and Asia. ${ }^{3}$

The IS possesses a governmental authority, whose efficiency is ensured by a law enforcement agency and a judicial system. In addition, it has its own financial and economic resources, coming in particular from the sale of oil and extortion. ${ }^{4}$ However, the IS exercises its power over a territory whose borders are regularly moving, depending on the military successes of the coalition engaged in a conflict against that organization. ${ }^{5}$ It is doubtful whether the territory of the IS is steady enough in order to be considered as a State territory. ${ }^{6}$ In any case, since the IS has acquired its territory through an illegal use of armed force and, more generally, rejects the rules of the international legal order, it should not - and is not - recognised as a State. ${ }^{7}$ An entity whose statehood is not recognised by any State, cannot emerge as a State in the international legal order. There is a general consensus in the international community that the IS is a terrorist organization. ${ }^{8}$

In response to attacks of the IS, Iraq asked in June 2014 for international assistance in its fight against the organization in Iraq. ${ }^{9}$ Then, in September 2014, Iraq requested the United States and its allies to assist it in defending itself against the group also in Syria. It noted that the IS had established a safe haven outside Iraq that provided the group an ability "to train for, plan, finance and carry out terrorist operations across our borders." For these reasons, Iraq asked the United States to "lead international efforts to strike ISIL sites and military strongholds, with our express consent." 10 This request was the doorway through which the United States and other States alleged a right to assist Iraq in its fight against the IS in Iraq and/or Syria. In August 2014, the United States launched airstrikes against the IS in Iraq and, in September 2014, expanded its military intervention against the organization in Syria. At the same time, it declared airstrikes against the Khorasan Group in Syria, a group which is composed by al-Qaeda elements. ${ }^{11}$ Bahrain, Qatar, Jordan, Saudi Arabia, and the United Arab Emirates immediately participated in the United States-led airstrikes against the IS in Syria. Canada, Turkey, 
Australia, France, the United Kingdom, Germany, Denmark, the Netherlands, Belgium, and Norway joined the coalition later. ${ }^{12}$ While some of those States participate in the airstrikes against the IS in Iraq and/or Syria, such as in particular the UK and France, others simply provide military assistance, like Germany. ${ }^{13} 64$ States and 2 international organizations are militarily involved against the IS in Iraq. ${ }^{14}$ Only 16 States are involved in the military action against the IS in Syria. The difference in the number of States implicated in the fight against the IS in Iraq and Syria is due to the fact that, while the legality of the military involvement is overall uncontentious in Iraq, at least in the jus ad bellum aspect, it is not the case of the military involvement in Syria.

A State can request armed assistance from other States on its territory, in particular to defeat terrorist movements. Under international law, external military intervention by invitation is legal, except when its objective is to settle a civil war in favour of the established government. ${ }^{15}$ Consent by the territorial State to the resort to force by other States on its territory precludes the wrongfulness of the military intervention in relation to the intervening State(s). ${ }^{16}$ Only the effective authorities of the State have the lawful authority to consent and the consent must be given prior to the use of force, clear as well as free. The host State is entitled to set limits, in particular concerning the duration or the location of the State's use of force. ${ }^{17}$ The lawful government of Iraq explicitly and freely asked for military support in its fight against the IS on its territory. Thus, military involvement of States in Iraq against the IS since September 2014, with the consent of that latter State, is legal.

Unlike Iraq, Syria has not given its agreement to the military intervention of Iraq, the United States and several other States against the IS on its territory. On the contrary, Syria objected to the United States-led military action against the IS within its territorial confines, done without its approval, qualifying it as "a violation of Syrian sovereignty." 18 Russia too has been perpetrating strikes in Syria since September 2015 but these happen at the explicit and free request of the Syrian President, al-Assad. ${ }^{19}$ The regime of al-Assad can be regarded as the most effective authority in Syria, able to represent the Syrian State, nationally and internationally, contrary to the Syrian National Coalition. This regime is thus the government of Syria. ${ }^{20}$ Iran has also sent troops into Syria with the agreement of al-Assad. ${ }^{21}$ Russia's and Iran's military actions in Syria are thus based on the consent of that latter State and therefore legal, at least as long as they are directed against the IS and not against the opposition of the regime of al-Assad.

There are two clear exceptions to the international prohibition on the use of armed force between States: the use of force authorised by the UN Security Council, and the use of force within the right to self-defence. The 
UN Security Council can, on the basis of Chapter VII of the UN Charter, authorise States to resort to armed force against a State or non-State actor whose conduct is qualified as a threat to the peace, breach of the peace or act of aggression. It is common practice that the Security Council delegates the use of force to States in authorising them to use all necessary measures or all necessary means. ${ }^{22}$ Following the terrorist attacks in Paris and Saint-Denis on $13^{\text {th }}$ November 2015, the Security Council adopted Resolution 2249. It condemned a series of terrorist attacks by the IS, including those in France, and qualified the IS and other terrorist groups as "a global and unprecedented threat to international peace and security." ${ }^{, 23}$ Although Resolution 2249 does not explicitly refer to Chapter VII, this does not necessarily mean that it is not to be understood as binding, as stated by the International Court of Justice (ICJ). ${ }^{24}$ The resolution called upon "Member States that have the capacity to do so to take all necessary measures" in order, in particular, to eradicate the safe havens those terrorist groups have established over Iraq and Syria. ${ }^{25}$ The verb "calls upon" could be understood as an authorisation. ${ }^{26}$ The drafting history of resolution 2249 indicates however that the Security Council members did not want to adopt any binding resolution which authorised a military action. Based on an analysis of the text of resolution 2249 that differs from classical resolutions delegating the recourse to force, and on a reading of the debate having preceded its adoption, one can conclude that resolution 2249 did not confer a right to Member States they did not otherwise already have and did not authorise them to use force against the IS.

The other exception to the prohibition on the resort to inter-State armed force is the use of force within the right to self-defence, as recognised by the UN Charter (Article 51) and customary international law, in reaction to an armed attack. An action in self-defence can be individual, when the victim State reacts to an armed attack, or collective, when other States react to an armed attack on the request of the victim State. Not all States intervening in Syria gave a justification for their military action against the IS. Surprisingly, if Iraq sent two letters to the UN Security Council informing it about its military action against the IS, including in Syria, it did not refer to selfdefence or to Article 51 of the UN Charter. Iraq only mentioned that "ISIL has repeatedly launched attacks against Iraqi territory from eastern Syria." 27 Since however Iraq followed the obligation to report self-defence responses to the Security Council, as established by Article 51 of the UN Charter, it is here argued that Iraq implicitly justified its forcible action in Syria under the right to self-defence. The United States, Canada, and Turkey invoked the right to collective self-defence of Iraq as well as their right to individual self-defence, ${ }^{28}$ whereas Australia only invoked the right to collective self-defence of Iraq. ${ }^{29}$ France began its military intervention in 
Syria in September 2015 on the basis of its right to collective self-defence of Iraq. ${ }^{30}$ After the terror attacks of the IS in Paris and Saint-Denis on $13^{\text {th }}$ November 2015, France extended its strikes, on the ground of its right to individual self-defence and asked for assistance. ${ }^{31}$ Several western States decided then to be involved in the fight against the IS in Syria, invoking the right to self-defence. The United Kingdom relied on both the rights to individual and collective self-defence. ${ }^{32}$ Germany referred to the right to collective self-defence of States that had been subjected to armed attacks by the IS. ${ }^{33}$ Denmark, the Netherlands, Belgium, and Norway asserted that they were exercising collective self-defence of Iraq. ${ }^{34}$ Belgium claimed a right to collective self-defence of Iraq as well as of States that had been subjected to armed attacks by the IS. ${ }^{35}$

The conduct of the IS cannot be attributed to the al-Assad government and thus to Syria. Indeed, under international law, the conduct of a person or group of persons may be attributed to a State under six circumstances: if the entity is a de jure or de facto organ of the State ${ }^{36}$ if it is empowered by that State to exercise governmental authority; ${ }^{37}$ if it is an organ of another State that has been placed at the disposal of the first State; ${ }^{38}$ where the acting entity did so under the instructions, direction or control of the government of the State ${ }^{39}$ where the acting entity is "exercising elements of the government authority in the absence or default of the official authorities and in circumstances such as to call for the exercise of those elements of authority;" ${ }^{40}$ if the conduct is acknowledged and adopted by the State as its own. ${ }^{41}$ None of these attribution's criteria applies here. The IS is not an organ of Syria or of any other State; it has not been empowered by Syria in the exercise of governmental authority; it is acting independently from the Syrian State; furthermore, Syria objects to the operations of the IS, what prevents those operations being seen as elements of governmental authority in the default of the exercise of authority by the regular Syrian government on parts of the Syrian territory; ${ }^{42}$ finally, the IS's conduct has not been acknowledged by Syria. In fact, the al-Assad government does not exercise any control over the IS and has been engaged for years in a fight against the group. ${ }^{43}$ Thus, the IS's behaviour cannot be attributed to the Syrian State or to any other State. Furthermore, as stated above, the IS is not a State. Therefore, the IS must be seen as a non-State actor.

The right to self-defence is traditionally exercised by a State against another State. Hence, the question is raised of the legality of the action in self-defence by some States against the IS, a non-State actor, in Syria. In accordance with the UN Charter, the right to self-defence should be a response to an armed attack. The United States, Canada, Turkey, France, and the United Kingdom have however relied on their own right to individual self-defence in response to imminent armed attacks or even a simple 
threat of armed attacks by the IS. Thus, the question is raised on whether there is a new right to self-defence, under customary international law, in reaction to future armed attacks. This article aims to analyse whether the fight against the IS in Syria modified the material and temporal scopes of the customary right to self-defence. Four chapters will follow. Chapter 2 will argue that there was no right to self-defence against non-State actors before the Syrian conflict and will outline the arguments presented by some States in favour of a right to self-defence against the IS, a non-State actor. Chapter 3 will explain that, in contradiction with the traditional temporal understanding of the right to self-defence, some of the States intervening in Syria assert a right to react to imminent armed attacks or even to a simple threat of armed attacks committed by the IS. Chapter 4 will show the limited international acceptance of a broad right to self-defence as a justification for the military involvement in Syria. Finally, the last chapter will conclude that neither a right to self-defence against non-State actors, nor a right to self-defence in reaction to armed attacks whose occurrence is not certain, has crystallised in customary international law. The paper acknowledges however that the military operation against the IS in Syria constitutes another step towards the emergence of a customary right to selfdefence against non-State actors, including in reaction to future armed attacks, and argues that such a right should apply restrictively.

\section{An Action in Self-Defence against the IS as a Non-State Actor}

\subsection{The Absence of a Right to Self-Defence against Non-State Actors before the Fight against the IS}

The right to self-defence is guaranteed in Article 51 of the UN Charter as well as in customary international law. ${ }^{44}$ The bedrock principle of self-defence is that it may be invoked in response to an international armed attack. In its Nicaragua Judgment, the ICJ referred to Article 3(g) of the Definition of Aggression appended to a resolution of 1974 of the UN General Assembly as concerning an "armed attack." ${ }^{45}$ The Definition of Aggression can thus be used to define the concept of armed attack. Article 2 of this definition states that aggression is “...the use of armed force by a State against the sovereignty, territorial integrity or political independence of another State...." ${ }^{46}$ Article 2 of the Definition of Aggression also specifies that an act of aggression must be of "sufficient gravity." Similarly, the ICJ has stated that the "most grave forms of the use of force" constitute armed attacks. ${ }^{47}$ Furthermore, for the Court, an armed attack must be carried out "...with the specific intention of harming" a State - e.g. of harming the vessels of a State. ${ }^{48}$ Finally, an armed 
attack must be directed from outside territory controlled by the victim State. ${ }^{49}$ Therefore, an armed attack must correspond to a severe international use of armed force with a hostile character. The scope, duration and intensity of the armed force must be assessed to determine whether an armed attack has occurred. Today, terrorist groups have the capability to perpetrate attacks as grave as those of States. The IS for instance has clearly committed attacks that have crossed the threshold of armed attacks. In particular, the organization has launched full-scale invasions into Iraq and Syria, taking control of significant parts of their territory. ${ }^{50}$

The UN Charter and other regional defensive treaties do not envisage military defence against attacks committed by non-State actors. On the other hand, they do not exclude them. As famously declared by Judge Higgins: "[t]here is nothing in the text of Article 51 [UN Charter] that ... stipulates that self-defence is available only when an armed attack is made by a State." ${ }^{, 51}$ Could the State that is victim of an armed attack exercise its right to self-defence against a non-State actor, like the IS, author of the attack? The ICJ has clearly stated that the Charter only "recognizes the existence of an inherent right of self-defence in the case of armed attack by one State against another State" (we emphasize). ${ }^{52}$ In another case, it declined to elaborate on whether actions by non-State actors would constitute an armed attack that would trigger an armed defensive response. ${ }^{53}$ The fundamental problem here lies in the fact that non-State actors perpetrating armed attacks against a State do not normally reside in sovereignty-free areas (like in the high sea or in space). Thus, to admit the existence of a right to selfdefence against non-State actors would almost always have an impact on the territorial integrity of a State. This would violate Article 2 paragraph 4 of the Charter, that also reflects customary international law, ${ }^{54}$ which prohibits the use of armed force against the territorial integrity of States.

The law of self-defence is guaranteed under the UN Charter and customary international law. In accordance with a traditional interpretation of that law, self-defence is resorted to against a State. An interpretation of a treaty or a customary international norm can, however, be modified by customary international law. ${ }^{55}$ That law emerges through the combination of practice and opinio juris - the feeling that the practice is binding - that are repeated over a certain period of time, in a consistent way, and shared by a generality of States, including States whose interests are specially affected by the practice. ${ }^{56}$ Did the practice and the belief of States support the emergence of a customary right to self-defence against non-State actors?

States, in particular the United States and Israel, have sometimes used force against non-State actors. Thus, after the attacks of September 11 by the al-Qaeda terrorist organization on the American territory, the United States and its allied justified their resort to force against al-Qaeda terrorist camps 
and military installations of the Taliban regime in Afghanistan on the basis of their right to individual or collective self-defence. ${ }^{57} \mathrm{Al}$-Qaeda had planned its terrorist activities in Afghanistan with the passive support of that State. Following the dismantlement of the Taliban regime in December 2001, action in self-defence on the part of the United States and its allies was no longer directed against the State of Afghanistan, but directly against the Taliban and al-Qaeda, then both non-State actors. At least at the beginning, the military intervention received a broad international support. ${ }^{58}$ In 2006, Israel took action in self-defence against the Hezbollah organization in Lebanon, declaring that it was acting not against the State of Lebanon - to which it was not able to attribute Hezbollah's conduct - but against Hezbollah itself, a non-State actor. ${ }^{59}$ Although many States criticised the disproportionate way in which Israel exercised its right to self-defence, they agreed as a matter of principle that Israel had a right to self-defence to react to the attacks of Hezbollah. ${ }^{60}$ When, in other precedents, States invoked the right to self-defence against non-State actors, in particular terrorist organizations, third States were, however, reluctant to recognise the legality of the forcible action. ${ }^{61}$ Thus, in recent State practice, there was not quite a general and clear approval of the legality of the right to self-defence against non-State actors, even when they acted from a State that supported them or that failed to prevent its territory from being used as a base for their attacks. It is here argued that a right to self-defence against non-State actors was in the process of emerging. However, given the lack of broadness and consistency of both State practice and opinio juris, a right to self-defence in response to armed attacks by non-State actors had not crystallised in customary international law prior to the military intervention against the IS in Syria.

\subsection{The Allegation of a Right to Self-Defence against the IS}

A total of 11 States explicitly invoked a right to self-defence against the IS in Syria, namely the United States, Canada, Turkey, Australia, France, the United Kingdom, Germany, Denmark, the Netherlands, Belgium, and Norway. The exercise of self-defence in Syria, without its explicit consent, affects its territorial integrity. Thus, some of the intervening States advanced a reason, other than the need to react to armed attacks, to justify entering into Syria's territory.

In accordance with the ICJ, every State must not "allow knowingly its territory to be used for acts contrary to the rights of other States." ${ }^{, 62}$ States have a customary obligation to ensure that the area under their jurisdiction is not used in detriment of other States. Therefore, States should prevent their territory - or any other area under their exclusive control - to be used as a 
base for international offensives by terrorist organizations. Security Council Resolution 1373 obliges States to "[d]eny safe haven to those who finance, plan, support, or commit terrorist acts, or provide safe havens...." ${ }^{, 33}$ The Syrian State does indeed try to prevent the development of international terrorist activities by the IS from its territory. It has been locked in an internal conflict against the IS for years now, but struggles to put an end to its extra-territorial offensive action. The United States, Canada, Australia, and Turkey have stated in their letters reporting their action in self-defence against the IS in Syria to the UN Security Council, that Syria is "unwilling or unable" to prevent attacks emanating from the IS from its territory. ${ }^{64}$ Similarly, the British Prime Minister referred to the right to self-defence against the IS in Syria and to the fact that "the al-Assad regime is unwilling and/or unable to take action necessary to prevent ISIL's continuing attack on Iraq - or indeed an attack on us." ${ }^{65}$ Thus, for those States, their right to selfdefence against the IS in Syria is justified for two reasons: first, in reaction to ongoing, imminent or even possible armed attacks by the IS; second, because Syria, is "unwilling or unable" to prevent the IS from launching those attacks from its territory. Here, the justification for the use of the right to self-defence lies in the existence of armed attacks by a non-State actor and in the unwillingness or inability of the territorial State to address those attacks. ${ }^{66}$ If a closer analysis is done of the consequences of the unwillingness or inability of the territorial State, it appears that it exonerates the victim State of any responsibility for the incidental breach of the territorial State's sovereignty in the course of self-defence by the victim State. ${ }^{67}$

This understanding of the right to self-defence had already been explicitly invoked by a few States in the past. For instance, Israel claimed a right to self-defence against the Palestinian Liberation Organization in Lebanon, in 1981, because Lebanon was "unwilling or unable to prevent the use of its territory" by that organization to attack Israel. ${ }^{68}$ In 1996, Turkey asserted that it had a right to act in self-defence against Partiya Karkerên Kurdistanê (PKK) in Iraq because Iraq was "unwilling or unable to prevent the use of its territory" for attacks by that group ${ }^{69}$ Similarly, in 2002, Russia advanced that since Georgia was "unable to establish a security zone in the area of the Georgian-Russian border," and thus to put an end to attacks by non-State actors against Russia, it reserved to act in self-defence. ${ }^{70}$ Reference can also be made to declarations of high-ranking US officials who supported the unwilling or unable test. The Legal Advisor to the State Department of State, under the Bush administration, stated that: "[a] state must prevent terrorists from using its territory as a base for launching attacks. As a legal matter, where a state is unwilling or unable to do so, it may be lawful for the targeted state to use military force in self-defence to address that threat." ${ }^{, 71}$ 
His successor under the Obama administration shared the same position. ${ }^{72}$ Overall however, actions in self-defence against non-State actors launching armed attacks, under the justification that the territorial State was unwilling or unable to deal with the situation, was received with only little explicit support by other States. ${ }^{73}$

As proposed by its proponents, the unwilling or unable test requires the victim State itself to assess as accurately as possible whether the territorial State is willing or able to address armed attacks committed by a non-State actor from within its territory. ${ }^{74}$ The obligation of a State to prevent its territory to be used for the perpetration of armed attacks against other States is "an obligation of means, not an obligation of results."75 Thus, Syria has the obligation to do whatever possible in the particular circumstances aiming at the suppression of extraterritorial terrorist activities by the IS within its territorial confines. At the beginning of the emergence of the IS, Syria was not fully committed to defeat this group. There is evidence that the regime of al-Assad allowed the IS to establish a safe haven on its territory. ${ }^{76}$ It is not the case anymore. Syria is engaged in a conflict against the IS and thus willing to suppress it. Concerning the inability test, it can indeed be argued that Syria has proved unable to prevent the IS from using its territory to launch international attacks. Syrian troops have withdrawn from many regions in Syria and have difficulties in others in the fight against the IS. Syria lacks control over large parts of its territory from which the IS operates. ${ }^{77}$ Syria is clearly unable to deal, on its own, with the terrorist organization. It must then ask other States for assistance. Otherwise, it would violate its obligation of due diligence to prevent armed attacks emanating from its territory. ${ }^{78}$ Syria has indeed stated that it wishes to cooperate with the United States and other States to combat the IS, but those States do not want to be associated with Syria as long as the regime of al-Assad remains in place. ${ }^{79}$ For instance, the United States has said that "[i]n the fight against ISIL, we cannot rely on an Assad regime that terrorizes its own people." ${ }^{80}$ In this author's view, the offer made by Syria to collaborate with other States in the fight against the IS should not be rejected as long as it is given clearly, freely, and by the proper government of Syria, regardless of the serious violations of international law committed by that government. The Syrian State should be regarded as willing to address the IS's armed attacks, as long as it expresses its consent, through its government, to control the organisation in cooperation with other State(s). 


\section{An Action in Self-Defence in Reaction to Future Armed Attacks by the IS}

\subsection{The Allegation of a Right to Anticipatory Self-Defence against the IS}

Under Article 51 of the UN Charter, an armed attack must "occur" to justify a response in self-defence. ${ }^{81}$ The action in self-defence must be reported to the UN Security Council that shall take measures necessary to maintain international peace and security. What is contemplated by the Charter is that States have the right to respond to an armed attack only for the period that it takes for the Security Council to be notified, and for the necessary action to be taken to restore international peace and security.

Another temporal interpretation of the right to self-defence argues that such a right exists in an anticipatory way, to prevent an armed attack that is about to commence. The right to anticipatory self-defence departs from the text of Article 51 of the UN Charter but could have emerged in customary international law since the drafting of the Charter. ${ }^{82}$ Most academics, including the present author, consider that it would be unrealistic to expect a State, which detects preparations of an armed attack, to wait until this attack finally takes place. ${ }^{83}$ Whether an armed attack may be regarded as imminent, should be determined by reference to all relevant circumstances. In order to assess the imminence, as many academics frequently do, resort can be made to the criteria used by the American Secretary of State Daniel Webster in the Caroline case. ${ }^{84}$ He stated that preventive action by a foreign State is confined to cases in which the necessity of that self-defence is "instant, overwhelming, leaving no choice of means, and no moment for deliberation." ${ }^{\prime 85}$

In practice, the Caroline criteria are rarely literally applied. States resort to anticipatory self-defence not only to react to an impending armed attack that will be initiated within minutes or hours but also to avert an armed attack, when there is a credible certainty that it will be launched in the foreseeable future. ${ }^{86}$ They had a broad interpretation of the imminence of an armed attack. For instance, the military intervention in Afghanistan in October 2001 intended to halt further terrorist attacks from the al-Qaeda organization, and not attacks that were about to materialise. The United States explained that its action was "designed to prevent and deter further attacks on the United States." ${ }^{87}$ Similarly, the United Kingdom argued that its participation in collective self-defence in the military operation was "to avert the continuing threat of attacks." ${ }^{88}$ Overall, States have expressed different views on the legality of a right to self-defence in reaction to armed attacks that are very likely to occur in an immediate future. ${ }^{89}$ It is here argued that the right to self-defence in reaction to a future armed attack that is not sure to happen, was not sufficiently supported by State practice and 
opinio juris, and had not crystallised in customary international law before the conflict in Syria. ${ }^{90}$

A broad understanding of the concept of armed attack is shared by some of the States militarily involved against the IS in Syria. Turkey launched its first airstrikes against the IS in Syria in July 2015, referring to its right to individual and collective self-defence. It then relied on the existence of a "clear and imminent threat of continuing attack from Daesh" (we emphasize) and not in the existence of a clearly imminent attack. ${ }^{91}$ The United Kingdom also adopted a quite extensive understanding of the condition of imminence in the exercise of the right to anticipatory self-defence. It killed two British citizens in a drone strike in Syria in August 2015, arguing that it was acting under the right to individual self-defence against the IS. One of the individuals killed was, as stated by the United Kingdom, "engaged in planning and directing imminent armed attacks against the United Kingdom" (we emphasize). ${ }^{92}$ The United Kingdom thus only referred to prospective attacks and not to attacks that were about to be perpetrated. France reacted similarly. France extended its strikes against the IS in Syria after the Paris and SaintDenis attacks of $13^{\text {th }}$ November 2015. The attackers were not under direct instructions from the IS's commanders. The IS however acknowledged and adopted the French attacks as its own. The Paris and Saint-Denis terrorist acts can thus be attributed to that organization. ${ }^{93}$ Those attacks that killed 130 and seriously injured 413 people can be seen as reaching the level of an armed attack. ${ }^{94}$ It was thought that the IS would commit or acknowledge other attacks - a fear confirmed with the terrorist attack in Nice on 14 July that killed 86 people and was acknowledged by the IS. ${ }^{95}$ When France began its action in individual self-defence against the IS in Syria in November 2015, it was however unclear whether the group was about to launch armed attacks against France. France then reacted to armed attacks that were not in the process of being committed. Thus, Turkey, the United Kingdom, and France resorted to their right to individual self-defence in reaction to armed attacks by the IS that were not about to happen, but were, at best, very likely to occur.

\subsection{The Allegation of a Right to Pre-emptive Self-Defence against the IS}

Following the attacks of $11^{\text {th }}$ September 2001, the United States adopted another, third temporal conception of the right to self-defence, where the armed attack is in a further distance than in the right to anticipatory selfdefence. The United States asserted that it had a right to pre-emptive selfdefence to react to potential armed attacks that if they took place would result in significant harm. The United States invoked in particular a right to pre-emptive self-defence against States developing weapons of mass destruc- 
tion, which they might use themselves against the United States or supply to terrorist organizations hostile to that State. ${ }^{96}$ The Bush administration claimed a right to use force before attacks occur, "even if uncertainty remains as to the time and place of the enemy's attack." ${ }^{97}$ It argued that circumstances had changed and the requirement of imminent attack should be adapted to the capabilities and objectives of today's adversaries. ${ }^{98}$ The current Obama administration did not seem to have departed from the pre-emptive selfdefence argument. ${ }^{99}$ Thus, the United States attempted to shift the parameters of immediacy and imminence of an armed attack to deal with a threat of an armed attack that could manifest itself at some point in the future. The notion of pre-emptive self-defence precludes any attempt to assess selfdefence claims objectively, instead giving to States the discretionary power to decide whether an uncertain future threat for their security justifies a resort to force. The pre-emptive self-defence doctrine, which would result both in a total redefinition of the concept of self-defence and the replacement of the present international law on the use of force, was not shared by other States and had thus not become customary before the beginning of the conflict against the IS. ${ }^{100}$

An extensive temporal conception of the right to self-defence has, however, been recently adopted by some States in their military action against the IS. The United States had not been victim of an armed attack by the IS an assault on a small number of captured Americans in Iraq and Syria cannot be considered to be an armed attack against the United States ${ }^{101}$ - when it began its self-defence intervention against the IS in Syria. ${ }^{102}$ Nevertheless, the United States claimed a right to individual self-defence against the IS. It stated that the IS and other terrorist groups were a "threat" to the United States triggering the right of countries, including the United States, to defend themselves "in accordance with the inherent right of individual and collective self-defence." ${ }^{103}$ The United States did not produce information about concrete preparations of an armed attack by that organisation against the country in a near future. Future attacks by the IS did not appear to be imminent, but looked like mere speculations. Similarly, the United States reported that it initiated a military intervention against elements of the Khorasan Group in Syria, on the basis of its right to individual self-defence, "to address terrorist threats that they pose to the United States and our partners and allies" (we emphasize). ${ }^{104}$ Again, United States officials did not provide any evidence of an imminent armed attack by the Khorasan Group. Like the United States, Canada has not been attacked by the IS. ${ }^{105}$ Canada relied however on its right to individual self-defence against the IS in Syria. It declared that "ISIL also continues to pose a threat not only to Iraq, but also to Canada and Canadians.... In accordance with the inherent rights of individual and collective self-defence reflected in Article 51 of the UN Charter, States must 
be able to act in self-defence..." (we emphasize). ${ }^{106}$ Canada did not give any precision concerning the imminence of an armed attack by the IS against that State. Like the United States and Canada, the United Kingdom has not been attacked by the IS. ${ }^{107}$ It also claimed a right to individual self-defence to react to only a threat of armed attacks perpetrated by the IS. The British Prime Minister referred to the threat posed by the IS to the United Kingdom and to seven terrorist plots to attack the country that were linked to the IS or inspired by its propaganda - therefore not all directed by that organization. ${ }^{108}$ In its letter reporting its action in self-defence in Syria, the United Kingdom explained that "ISIL/ Daesh members are known to be actively engaged in planning and directing attacks against the United Kingdom from Syria" (we emphasize). ${ }^{109}$ The United Kingdom did not however provide evidence that an armed attack by the IS was imminent. Thus, the United States, Canada, and the United Kingdom asserted a right to self-defence in order to react to a simple threat of armed attacks by the IS and not to occurring or imminent armed attacks.

\section{The Limited International Acceptance of a Broad Right to Self-Defence in Syria}

Before the fight against the IS in Syria, State practice and opinio juris revealed the emergence of a new interpretation of the right to self-defence, allowing the use of that right against non-State actors. ${ }^{110}$ Did the allegation of some of the intervening States in Syria in favour of a right to self-defence against the IS, a non-State actor, crystallise the right to self-defence against non-State actors in customary international law? Furthermore, some of the States involved in the US-led military coalition in Syria asserted the existence of a right to self-defence in reaction to future armed attacks by the IS. Did the military intervention in Syria lead to the emergence, in customary international law, of a right to anticipatory self-defence in response to very credible armed attacks, or even a right to pre-emptive self-defence in response to possible armed attacks?

As stated above in that article, 11 States explicitly referred to the right to self-defence to justify their military involvement against the IS in Syria. ${ }^{111}$ Among them, 5 States explicitly shared the unwilling and unable standard: the United States, Canada, Australia, Turkey, and the United Kingdom. ${ }^{112} 5$ States had a wide perception of the temporal requirement of the right to selfdefence, asserting it to react to imminent armed attacks - the imminence being broadly understood - or even to a simple threat of armed attacks: Turkey, the United Kingdom, France, the United States, and Canada. ${ }^{113}$ The allegation of a right to self-defence against the IS by 11 States, even if including powerful States, cannot however, on its own, crystallise a new 
interpretation of the right to self-defence. Such a new interpretation should be clearly supported by a majority of the international community.

It can first be looked at the reactions of international organizations towards the self-defence action against the IS in Syria. For the UN Security Council, "Member States that have the capacity to do so" are called upon "to take all necessary measures" in order to eradicate the safe havens those terrorist groups have established over Iraq and Syria. ${ }^{114}$ The term "capacity" is to interpret in an encompassing way. Resolution 2249 asks all UN Member States to take any kind of measure in the fight against the IS. This includes non-forcible measures as well as military measures. Although Resolution 2249 does not authorize the use of armed force, it encourages it. The Security Council was of course aware that the legal argument of most States militarily involved in Syria was the right to self-defence. Thus, the Security Council can be seen as supporting, but only implicitly, the right to selfdefence against the IS, a non-State actor, including in a preventive way. Similarly, the Council of the European Union implicitly endorsed the selfdefence justification for the military operation in Syria, when it activated the Mutual Defence clause in November 2015, after the Paris and Saint-Denis attacks. It then stated: "[i]f a Member State is the victim of armed aggression on its territory, the other Member States shall have towards it an obligation of aid and assistance by all the means in their power, in accordance with Article 51 of the UN Charter." ${ }^{, 15}$ Thus, both the UN Security Council and the Council of the European Union seem to approve the action in selfdefence against the IS in Syria, but only very cautiously.

The paper now turns to the reactions of States towards the self-defence intervention against the IS in Syria. 5 States participating in the military action in Syria did not articulate any legal justification for their participation, be it self-defence or other: Bahrain, Qatar, Jordan, Saudi Arabia, and the United Arab Emirates. ${ }^{116}$ This suggests that they are not ready to support the right to self-defence against the IS. Other States contested the legality of the military intervention in Syria, and thus rejected the existence of a right to self-defence against the IS. Syria objected to the legality of the use of force against the IS within its territorial confines, if done without its consent. ${ }^{117}$ Russia condemned American airstrikes on the IS in Syria. ${ }^{118}$ Iran stated that the American intervention in Syria was illegal. ${ }^{119}$ As allies of the al-Assad regime, Russia and Iran are indeed opposed to the use of force on Syrian territory without the agreement of the Syrian government. Some States, more generally, condemned any infringement of the sovereignty of a State, including that of Syria, even in the fight against the IS. ${ }^{120}$

The vast majority of the States not involved in the military operation in Syria has neither condemned nor supported it. ${ }^{121}$ They did not express any opinion on the legality of the action in self-defence. Could it be argued that 
the silence of a high majority of States not involved in the self-defence intervention against the IS in Syria towards the legality of that intervention, reflect an implicit acceptance of that legality? The role of silence or abstention could reveal the approval of a new customary practice only in the situation where States were conscious that they should object to the practice in order to prevent its emergence as a customary practice. This is a reasonable precaution, since a State may simply do nothing and mean nothing by it. ${ }^{122}$ It is doubtful whether States believed that their silence towards the legality of the action in self-defence against the IS in Syria could be interpreted as an acquiescence of that legality, especially concerning the legality of a practice related to the use of armed force. The prohibition of the resort to force by a State in another State without the explicit consent of the latter State is a norm of a higher legal value under international law, a peremptory norm of international law from which no derogation is possible in any international act. ${ }^{123}$ Given the legal importance of the prohibition on the use of force by a State on the territory of another State, it is here argued that a customary exception from it or the extension of an exception from it could emerge only if it is supported by an explicit opinio juris. Thus, States did very likely not want to support a broad right to self-defense, allowing the use of force by a State on the territory of another State in reaction to occurring or future armed attacks by a local non-State actor, when those States did not explicitly object to the recourse to force against the IS on the territory of Syria. The absence of explicit criticisms of many States towards the action in self-defence against the IS in Syria should not be regarded as revealing an opinio juris in favour of a new right to self-defence against a non-State actor or a new right to self-defence in reaction to future armed attacks. ${ }^{124}$ Furthermore, although 64 States and 2 regional organizations contribute in various capacities to the effort to combat the IS in Iraq, only 16 States participate in different ways in the military action against the IS in Syria. It is here submitted that the high difference in the number of States involved in the combat against the same non-State actor in Iraq and Syria is indicative of States' concerns as to the legality of the use of force in self-defence against the IS in Syria.

An instructive comparison can be made with the international support of the self-defence action against the al-Qaeda organization and the Taliban in Afghanistan in 2001. After the September 11 attacks, in Resolutions 1368 and 1373, the UN Security Council condemned those attacks and recognized or reaffirmed "the inherent right of individual and collective self-defence in accordance with the Charter." 125 The Security Council did not make express reference to an "armed attack" but instead to a "threat to international peace and security." However, on the other hand, the Security Council does not often explicitly refer to the right to self-defence. Thus, the inclusion of selfdefence in Resolutions 1368 and 1373 is significant and can be interpreted as 
an approval of the self-defence intervention in Afghanistan. On $12^{\text {th }}$ September 2001, the North Atlantic Council agreed that the attacks against the United States "shall be regarded as an action covered by Article 5 of the Washington Treaty," which states that an armed attack against one or more of the Allies in Europe or North America is an attack against them all. ${ }^{126}$ The North Atlantic Council thus recognised the legality of a collective self-defence reaction in Afghanistan. The Organization of American States also expressed support for the right to collective self-defence after the terrorist attacks. ${ }^{127}$ Furthermore, the military intervention in self-defence by the United States in Afghanistan, that begun on 7 October 2001, got the military assistance of the UK and pledges of military support from other States on the basis of their right to collective self-defence. ${ }^{128}$ In addition, the military defensive action in Afghanistan was received with several declarations of acceptance by other numerous States. ${ }^{129}$

The self-defence operation against the IS in Syria was not supported at the same level as the self-defence operation against al-Qaeda and the Taliban in Afghanistan. No international organizations have expressed explicit approval for the right to self-defence against the IS in Syria. Similarly, there were not numerous public assertions of support for that right. On the contrary, as seen above in that chapter, some States denounced the illegality of the unilateral military action in Syria.

\section{Conclusion}

The involvement of States and international organizations in the airstrikes against the IS in Syria is relatively weak, in particular in comparison to the involvement in the airstrikes against the same terrorist group in Iraq. Furthermore, the international community did not clearly support the allegation made by some of the intervening States in Syria of the existence of a right to self-defence against the IS as a non-State actor, or a right to selfdefence in response to future armed attacks by the IS. Therefore, it is here concluded that the military intervention against the IS in Syria did not lead to a crystallisation of a customary right to self-defence against a non-State actor or a customary right to anticipatory self-defence - in reaction to armed attacks that are very likely to happen - or pre-emptive self-defence - in reaction to a threat of armed attacks. Under current international law, there is not yet a right to self-defence against a non-State actor, even in a State that is not able or not willing to deal with the non-State actor. Similarly, there is not a right to self-defence in response to very likely armed attacks or, a fortiori, in response to only possible armed attacks. The fight against the IS has not broadened up the right to self-defence under customary international law. 
This fight constitutes however another precedent towards the emergence of a customary right to self-defence against non-State actors, including as a reaction to future armed attacks. If the right to self-defence against nonState actors finally crystallises, States should be careful in not broadening by too much its material and temporal scopes. Action in self-defence against non-State actors should be restricted to a few exceptional cases, when it appears to be really necessary. Furthermore, the moment as to when the right to self-defence could be legally exercised should not be too expanded. In this author's view, the temporal requirement of the right to self-defence should be interpreted with some flexibility when self-defence applies to nonState actors, especially terrorist organizations, whose attacks inherently rely on unpredictability and concealment. Implementation of the right to self-defence should however be restricted to situations where there is persuasive evidence of a concrete armed attack in the foreseeable future.

\section{NOTES AND REFERENCES}

1. It is also referred to as the "Islamic State of Iraq and Syria," or with its Arabic acronym, "Daesh" or "Da'esh."

2. BBC News, "Islamic State and the Crisis in Iraq and Syria in Maps," 30 November 2016. http://www.bbc.co.uk/news/world-middle-east-27838034 [8 Dec. 2016]

3. Yourish, K., D. Watkins, and T. Giratikanon, "Where ISIS Has Directed and Inspired Attacks around the World," 22 March 2016. http://www.nytimes.com/ interactive/2015/06/17/world/middleeast/map-isis-attacks-around-the-world.html?_r $=0[8$ Dec. 2016]

4. BBC News (n. 2)

5. In 2015 , the IS shrunk from $90,800 \mathrm{~km}^{2}$ to $78,000 \mathrm{~km}^{2}$, a net loss of $14 \%$. In the first nine months of 2016, that territory shrunk again by a further $16 \%$. As of 3 October 2016, the IS controls roughly $65,500 \mathrm{~km}^{2}$ in Iraq and Syria. HIS Markit, "Islamic State Caliphate Shrinks by 16 Percent in 2016, IHS Markit Says," 9 October 2016. http://www.businesswire.com/news/home/20161009005034/en/ Islamic-State-Caliphate-Shrinks-16-Percent-2016 [8 Dec. 2016]

6. Article 1 of the Montevideo Convention on the Rights and Duties of States, that is a statement of pre-existing customary international law, enumerates the characteristics of a State, namely a population, a territory, a government and the capacity to enter into relations with other States. Montevideo Convention on the Rights and Duties of States (adopted 26 December 1933, entered into force 26 December 1934).

7. In accordance with the principle of ex injuria jus non oritur, an illegal act cannot produce legal rights. See also "Articles on Responsibility of States for Internationally Wrongful Acts" in UNGE Res 56/83 (28 January 2002) UN Doc A/RES/56/83, Annex 1, 9, Art. 41. 
8. The IS has been designated as a terrorist organization by the UN, the European Union, the United States, and the United Kingdom, among others. See for instance Obama, B.H., "Address to the Nation on United States Strategy to Combat the Islamic State of Iraq and the Levant Terrorist Organization (ISIL)," Daily Comp Pres Docs, 2014 DCPD No 00654.

9. "Letter dated 25 June 2014 from the Permanent Representative of Iraq to the United Nations addressed to the Secretary-General" (25 June 2014) UN Doc S/2014/440, Annex.

10. "Letter dated 20 September 2014 from the Permanent Representative of Iraq to the United Nations addressed to the President of the Security Council" (22 September 2014) UN Doc S/2014/691.

11. O'Connor, L. (2016), "Legality of the Use of Force in Syria against Islamic State and the Khorasan Group," Journal on the Use of Force and International Law 3: 71 .

12. Ibid.; "Letter dated 7 June 2016 from the Permanent Representative of Belgium to the United Nations addressed to the President of the Security Council" (9 June 2016) UN Doc SC Res S/2016/523; "Letter dated 3 June 2016 from the Permanent Representative of Norway to the United Nations addressed to the President of the Security Council" (3 June 2016) UN Doc SC Res S/2016/513.

13. Germany does not participate in the bombing missions. The new leadership of Canada announced withdrawal from airstrikes in Iraq and Syria on 21 October 2015 but Canada remains a coalition partner. Murphy, J. (2015), "Canada to End Airstrikes in Syria and Iraq, New Prime Minister Trudeau Say," The Guardian, 21 October.

14. State Department, "Counter-Daesh Coalition" (2016). http://www.state.gov /s/seci/261626.htm [8 Dec. 2016]

15. Bannelier, K., and Christakis, Th. (2016), "Military Interventions against ISIL in Iraq, Syria and Libya, and the Legal Basis of Consent," Leiden Journal of International Law 29(3): 3-5.

16. "Articles on Responsibility of States for Internationally Wrongful Acts" (n. 7), 5, Art. 20.

17. Corten, C. (2010), The Law against War. Oxford and Portland: Hart Publishing, 266-276.

18. "Identical letters dated 17 September 2015 from the Permanent Representative of the Syrian Arab Republic to the United Nations addressed to the SecretaryGeneral and the President of the Security Council" (21 September 2015) UN Doc S/2015/719. See also "Identical letters dated 21 September 2015 from the Permanent Representative of the Syrian Arab Republic to the United Nations addressed to the Secretary-General and the President of the Security Council" (22 September 2015) UN Doc A/70/385-S/2015/727. Syria condemned the action in self-defence by members of the US-led coalition on its territory in several other letters.

19. "Letter dated 15 October 2015 from the Permanent Representative of the Russian Federation to the United Nations addressed to the President of the Security Council" (15 October 2015) UN Doc S/2015/792, Annex.

20. Bannelier and Christakis, 2016 (n. 15): 20.

21. Ibid., 18. 
22. UNSC Res 678 (29 November 1990) UN Doc S/RES/678, para. 2; UNSC Res 1973 (17 March 2011) UN Doc S/RES/1973, para. 4.

23. UNSC Res 2249 (20 November 2015) UN Doc S/RES/2249, preamble.

24. ICJ, Legal Consequences for States of the Continued Presence of South Africa in Namibia (South West Africa) notwithstanding Security Council Resolution 276 (1970), Advisory Opinion of 21 June 1971, ICJ Rep. 1971, 53.

25. UNSC Res 2249 (20 November 2015) UN Doc S/RES/2249, para. 5.

26. As it was when the SC resolution 211 (1966) allowed the United Kingdom to use force. UNSC Res 221 (9 April 1966) UN Doc S/RES/221.

27. "Letter dated 25 June 2014 from the Permanent Representative of Iraq to the United Nations addressed to the Secretary-General" (n. 9), Annex; "Letter dated 20 September 2014 from the Permanent Representative of Iraq to the United Nations addressed to the President of the Security Council" (n. 10).

28. "Letter dated 23 September 2014 from the Representative of the United States of America to the United Nations" (23 September 2014) UN Doc S/2014/695; "Letter dated 31 March 2015 from the Chargé d'affaires a.i. of the Permanent Mission of Canada to the United Nations addressed to the President of the Security Council" (31 March 2015) UN Doc S/2015/221; "Letter dated 24 July 2015 from the Chargé d'affaires a.i. of the Permanent Mission of Turkey to the United Nations addressed to the President of the Security Council" (24 July 2015) UN Doc S/2015/563.

29. "Letter dated 9 September 2015 from the Permanent Representative of Australia to the United Nations addressed to the President of the Security Council" (9 September 2015) UN Doc S/2015/693.

30. "Identical letters dated 8 September 2015 from the Permanent Representative of France to the United Nations addressed to the Secretary-General and the President of the Security Council" (30 September 2015) UN Doc S/2015/745. It was first not clear whether France referred to its right to collective self-defence on behalf of Iraq or to its independent right to self-defence. The French prime minister declared however on 15 September 2015 that France acted in Syria on the basis of its right to collective self-defence. Declaration of the Prime Minister on the sending of aerial forces above the Syrian territory, National Assembly, Second extraordinary session of 2014-2015, Tuesday 15 September. http://www.assemblee-nationale.fr/14/cri/ 2014-2015-extra2/20152001.asp [8 Dec. 2016]

31. Statement of France in UNSC Verbatim Record (20 November 2015) UN Doc S/PV.7565, 2.

32. "Letter dated 3 December 2015 from the Permanent Representative of the United Kingdom of Great Britain and Northern Ireland to the United Nations addressed to the President of the Security Council" (3 December 2015) UN Doc S/2015/928.

33. "Letter dated 10 December 2015 from the Chargé d'affaires a.i. of the Permanent Mission of Germany to the United Nations addressed to the President of the Security Council" (10 December 2015) UN Doc S/2015/946. Germany is only taking part in non-forcible missions.

34. "Letter dated 11 January 2016 from the Permanent Representative of Denmark to the United Nations addressed to the President of the Security Council" (13 
January 2016) UN Doc S/2016/34; "Letter dated 10 February 2016 from the Chargé d'affaires a.i. of the Permanent Mission of the Netherlands to the United Nations addressed to the President of the Security Council" (10 February 2016) UN Doc S/2016/132; "Letter dated 3 June 2016 from the Permanent Representative of Norway to the United Nations addressed to the President of the Security Council" (n. 12).

35. "Letter dated 7 June 2016 from the Permanent Representative of Belgium to the United Nations addressed to the President of the Security Council" (n. 12).

36. "Articles on Responsibility of States for Internationally Wrongful Acts" (n. 7), Annex 1, 2-3, Art. 4.

37. Ibid., Annex 1, 3, Art. 5.

38. Ibid., Annex 1, 3, Art. 6.

39. Ibid., Annex 1, 3, Art. 8.

40. Ibid., Annex 1, 3, Art. 9.

41. Ibid., Annex 1, 3, Art. 10.

42. According to the ILC Commentary, the application of Article 9 of the Draft Articles on Responsibility of States for Internationally Wrongful Acts requires that the States concerned had knowledge of the operations by the private person or group of persons and did not specifically object to them. Draft Articles on Responsibility of States for internationally Wrongful Acts, with commentaries 2001, 49. http:// legal.un.org/ilc/texts/instruments/english/commentaries/9_6_2001.pdf [8 Dec. 2016]

43. Those facts are attested by diverse independent sources, including the reports regularly prepared by the UN Secretary-General. See for instance Report of the Secretary-General on the Implementation of Security Council resolutions 2139 (2014), 2165 (2014), 2191 (2014) and 2258 (2015) (16 August 2016), UN Doc S/2016/714, part II A.

44. ICJ, Military and Paramilitary Activities in and against Nicaragua (Nicaragua v. United States of America), Judgment of 27 June 1986, ICJ Rep. 1986, para. 176.

45. Ibid., para. 195.

46. UN Doc A/RES/3314.

47. ICJ, Military and Paramilitary Activities in and against Nicaragua (n. 44), para. 191.

48. ICJ, Case Concerning Oil Platforms (Islamic Republic of Iran v. United States of America), Judgment of 6 November 2003, ICJ Rep. 2003, para. 64.

49. ICJ, Legal Consequences of the Construction of a Wall in the Occupied Palestinian Territory, Advisory Opinion of 9 July 2004, ICJ Rep. 2004, para. 139.

50. See infra chapter 1.

51. ICJ, Legal Consequences of the Construction of a Wall in the Occupied Palestinian Territory, Advisory Opinion of 9 July 2004, Separate Opinion Higgins, ICJ Rep. 2004, para. 33.

52. ICJ, Legal Consequences of the Construction of a Wall in the Occupied Palestinian Territory (n. 49), para. 139

53. ICJ, Case Concerning Armed Activities on the Territory of the Congo (Democratic Republic of the Congo v. Uganda), Judgment of 19 December 2005, ICJ Rep. 2005, para. 147. 
54. ICJ, Case Concerning Military and Paramilitary Activities in and against Nicaragua (n. 44), para. 185.

55. Subsequent State practice in the application of a treaty can modify the interpretation of the treaty if it establishes the agreement of the parties regarding the new interpretation. Vienna Convention on the Law of Treaties (adopted 22 May 1969, entered into force 27 January 1980) Art. 313 b.

56. ICJ, North Sea Continental Shelf cases (Federal Republic of Germany v. Denmark; Federal Republic of Germany v. The Netherlands), Judgment of 20 February 1969, ICJ Rep., paras 73-74 and 77.

57. "Letter dated 7 October 2001 from the permanent representative of the United States of America to the United Nations addressed to the President of the Security Council" (7 October 2001) UN Doc S/2001/946.

58. See infra chapter 4.

59. "Identical letters dated 12 July 2001 from the Permanent Representative of Israel to the United Nations addressed to the Secretary-General and the President of the Security Council" (12 July 2006) UN Doc A/60/937-S/2006/515.

60. Van Steenberghe, R. (2010) "Self-defense in Response to Attacks by NonState Actors in the Light of Recent State Practice: A Step Forward?," Leiden Journal of International Law 23(1): 193; Ruys, T. (2010), “Armed Attack” and Article 51 of the UN Charter. Cambridge: Cambridge University Press, 451-453.

61. For discussion of the State practice: Tams, C.T. (2009) "The Use of Force against Terrorists," European Journal of International Law 20(2): 379-381; Ruys, 2010 (n. 60), 447-449, 457-472 and 486-487.

62. ICJ, The Corfu Channel Case (United Kingdom v. Albania), Judgment of 9 April 1949, ICJ Rep. 1949, 22.

63. SC Res 1373 (28 September 2001) UN Doc S/Res/1373, para. 2 (c). See also Declaration on Principles of International Law concerning Friendly Relations and Cooperation among States in accordance with the Charter of the United Nations, GA Res 2625 (XXV), 25th sess, 1883rd mtg., (24 October 1970) UN Doc A/RES/2625.

64. "Letter dated 23 September 2014 from the Representative of the United States of America to the United Nations" (n. 28); "Letter dated 31 March 2015 from the Chargé d'affaires a.i. of the Permanent Mission of Canada to the United Nations addressed to the President of the Security Council" (n. 28); "Letter dated 9 September 2015 from the Permanent Representative of Australia to the United Nations addressed to the President of the Security Council" (n. 29); "Letter dated 24 July 2015 from the Chargé d'affaires a.i. of the Permanent Mission of Turkey to the United Nations addressed to the President of the Security Council” (n. 28) respectively.

65. Cameron, D. (2015), Statement in the House of Commons on His Response to the Foreign Affairs Select Committee (FAC) Report on Military Operations in Syria. https://www.gov.uk/government/speeches/pm-statement-responding-to-fac-reporton-military-operations-in-syria [8 Dec. 2016]

66. Deeks, A.S. (2011-2012), “'Unwilling or Unable': Toward a Normative Framework for Extraterritorial Self-Defense," Virginia Journal of International Law 52(3): 495. 
67. Tsagourias, N. (2016), "Self-Defence against Non-State Actors: The Interaction between Self-Defence as a Primary Rule and Self-Defence as a Secondary Rule," Leiden Journal of International Law 29(3): 25.

68. UNSC Verbatim Record (17 July 1981) UN Doc S/PV.2292, paras 54-63.

69. UNSC, "Identical letters dated 27 June 1996 from the Charge d'Affaires a.i. of the Permanent Mission of Turkey to the United Nations addressed to the Secretary-General and to the President of the Security Council" (2 July 1996) UN DOC S/1996/479, Annex.

70. UNSC, "Letter dated 11 September 2002 from the Permanent Representative of the Russian Federation to the United Nations addressed to the Secretary-General" (12 September 2002) UN Doc S/2002/1012, Annex.

71. Bellinger, J. (2007), "Armed Conflict with Al Qaida?," Opinio Juris, 15 January. http://opiniojuris.org/2007/01/15/armed-conflict-with-al-qaida/ [8 Dec. 2016]

72. Koh, H.H. (2010), US Legal Adviser, "The Obama Administration and International Law: Keynote Address at the American Society of International Law 104th Annual Meeting," 25 March. http://www.state.gov/s/1/releases/remarks/139 119.htm [8 Dec. 2016]

73. Reinold, Th. (2011), "State Weakness, Irregular Warfare, and the Right to Self-Defense Post-9/11," American Journal of International Law 105(2): 255-257 and 272; Hakimi, M. (2015), "Defensive Force against Non-State Actors: The State of Play," International Law Studies 91: 13-14; Williams, G.D. (2016), "Piercing the Shield of Sovereignty: An Assessment of the Legal Status of the "Unwiling or Unable' Test," University of New South Wales Law Journal 36: 633-638. For instance, when Russia attacked Chechen rebel forces in Georgia asserting that the Georgian State was "unwilling or unable" to prevent terrorist action launched from its territory, the United States itself did not accept this argument.

74. See in particular Deeks, 2011-2012 (n. 66): 495.

75. Lesperance, R.J. (2015), "Canada's Military Operations against ISIS in Iraq and Syria and the Law of Armed Conflict," Canadian International Lawyer 10(2): 58. See also Starski, P. (2015), "Right to Self-Defense, Attribution and the NonState Actor - Birth of the 'Unable or Unwilling' Standard?," Zeitschrift für ausländisches öffentliches Recht und Völkerrecht 75(3): 480.

76. Flasch, O. (2016), "Legality of the Air Strikes against ISIL in Syria: New Insights on the Extraterritorial Use of Force against Non-state Actors," Journal on the Use of Force and International Law 3: 61.

77. BBC News (n. 2). The lack of control by Syria over parts of its territory has been largely recognised by States and UN organs. See for instance SC resolutions making several references to the IS-uncontrolled areas in Syria: SC Res 2170 (15 August 2014) UN Doc S/Res/2170, preamble; SC Res 2249 (20 November 2015) UN Doc S/Res/2249, preamble and para. 5.

78. In that sense Trapp K.N. (2015), "Can Non-State Actors Mount to an Armed Attack," in Weller, M. (ed.), The Oxford Handbook of the Use of Force in International Law. Cambridge: Cambridge University Press, 695.

79. "Identical letters dated 21 September 2015 from the Permanent Representative of the Syrian Arab Republic to the United Nations addressed to the SecretaryGeneral and the President of the Security Council" (n. 18). See also "Identical letters 
dated 14 October 2015 from the Permanent Representative of the Syrian Arab Republic to the United Nations addressed to the Secretary-General and the President of the Security Council" (16 October 2015) UN Doc A/70/429-S/2015/789.

80. Obama, B.H. (2014), "Statement by the President on ISIL," 10 September, The White House. Office of the Press Secretary. https://www.whitehouse.gov/thepress-office/2014/09/10/statement-president-isil-1 [8 Dec. 2016]

81. The ICJ seems to require the existence of an armed attack for the right to self-defence to be triggered. It stated: "[i]n the case of individual self-defence, the exercise of this right is subject to the State concerned having been the victim of an armed attack." (we emphasise) Military and Paramilitary Activities in and against Nicaragua (n. 44), para. 195.

82. Murphy, S.D. (2005), "The Doctrine of Preemptive Self-Defense," Villanova Law Review 50(3): 711-713. In this author's view, even if anticipatory self-defence was permitted under customary international law before 1945, it was repealed by Article 51 UN Charter and thus ceased to apply to the States party to the Charter.

83. See for instance Wilmshurst, E. (2006), "The Chatham House Principles of International Law on the Use of Force in Self-Defence," International and Comparative Law Quarterly 55(4): 964; Report of the Secretary-General, "In Larger Freedom: Towards Development, Security and Human Rights for All" (21 March 2005) UN Doc A/59/2005, para. 124; Randelzhofer, A., and Nolte, G. (2012), "Article 51," in Bruno S. et al. (eds.), The Charter of the United Nations. 3rd edn. Oxford: Oxford University Press, 1423.

84. Wilmshurst, E. (2006), "The Chatham House Principles of International Law on the Use of Force in Self-Defence," International and Comparative Law Quarterly 55(4): 965; Randelzhofer and Nolte, 2012 (n. 83): 1423.

85. State Secretary Webster (1840-1841), British and Foreign State Papers 29: 1138.

86. Gill, T.D. (2007), “The Temporal Dimension of Self-Defense: Anticipation, Pre-emption, Prevention and Immediacy," in Schmitt M.N. and Pejic J. (eds.), International Law and Armed Conflict: Exploring the Faultiness. Leiden-Boston: Martinus Nijhoff Publishers, 129-139.

87. "Letter dated 7 October 2001 from the Permanent Representative of the United States of America to the United Nations addressed to the President of the Security Council" (n. 57).

88. "Letter dated 7 October 2001 from the Chargé d'affaires a.i. of the Permanent Mission of the United Kingdom of Great Britain and Northern Ireland to the United Nations addressed to the President of the Security Council" (7 October 2001) UN Doc S/2001/947.

89. Corten, 2010 (n. 17): 406-443; Ruys, 2010 (n. 60), 267-294 and 330-342.

90. The General Assembly Resolution 60/1, that adopted the 2005 World Summit Outcome, reaffirmed that the "provisions of the Charter are sufficient to address the full range of threats to international peace and security" and did not endorse the right to anticipatory self-defence. GA Res 60/1, World Summit Outcome (24 October 2005) UN Doc A/RES/60/1, para. 79. 
91. "Letter dated 24 July 2015 from the Chargé d'affaires a.i. of the Permanent Mission of Turkey to the United Nations addressed to the President of the Security Council" (n. 28).

92. "Letter dated 7 September 2015 from the Permanent Representative of the United Kingdom of Great Britain and Northern Ireland to the United Nations addressed to the President of the Security Council" (8 September 2015) UN Doc S/2015/688.

93. The rule of attribution of Article 11 of the Draft Articles on the Responsibility of States for Internationally Wrongful Acts is applied by analogy. It states: "[c]onduct which is not attributable to a State under the preceding articles shall nevertheless be considered an act of that State under international law if and to the extent that the State acknowledges and adopts the conduct in question as its own." UNGE Res 56/83 (28 January 2002) UN Doc A/RES/56/83, Annex 1, 4, Art. 11.

94. Piel, S., Cazi, E., and Seelow, S. (2015), "Attentats de Paris: l'assaut du Bataclan, raconté heure par heure," Le Monde, 30 December. http://www.lemonde. fr/attaques-a-paris/article/2015/12/30/13-novembre-l-assaut-du-bataclan-heure-parheure_4839440_4809495.html [8 Dec. 2016]

95. "Le bilan de l'attentat de Nice porté à 86 morts," Le Monde, 19 August. http://www.lemonde.fr/societe/article/2016/08/19/le-bilan-de-l-attentat-de-niceporte-a-86-morts_4985199_3224.html [8 Dec. 2016]

96. Bush, G. (2002), The National Security Strategy of the United States of America, 13-16. http://www.state.gov/documents/organization/63562.pdf [8 Dec. 2016]

97. Ibid., 15.

98. Ibid., 15.

99. The American National Security Strategies of 2010 and 2015 do not mention the right to self-defence and thus seem to implicitly support the position on selfdefence developed by President Bush. Obama, B. (2010), The National Security Strategy of the United States of America, and Obama, B. (2015), The National Security Strategy of the United States of America. https://www.whitehouse.gov/ sites/default/files/rss_viewer/national_security_strategy.pdf and https://www.whitehouse.gov/sites/default/files/docs/2015_national_security_strategy.pdf, respectively [8 Dec. 2016]

100. Gray, Ch. (2008), International Law and the Use of Force. 3rd edn. Oxford: Oxford University Press, 209-226 and 218-221; Ruys, 2010 (n. 60), 317-318, 322324 , and 336.

101. The beheadings of a few Americans by the IS in Iraq and Syria, as horrible these acts may be, do not reach the threshold of an armed attack and thus cannot be considered as an armed attack against the United States. Arimatsu, L., and Schmitt, M.N. (2014), "Attacking 'Islamic State' and the Khorasan Group: Surveying the International Law Landscape," Columbia Journal Transnational Law Bulletin 53(1): 13.

102. Since then an attack acknowledged by the IS killed 49 people in a nightclub in Orlando in Florida. It is however doubtful whether this attack reached the threshold of an armed attack. Ellis, R. (2016), "Orlando Shooting: 49 Killed, Shooter Pledged 
ISIS Allegiance," 13 June. http://edition.cnn.com/2016/06/12/us/orlando-nightclubshooting/ [8 Dec. 2016]

103. "Letter dated 23 September 2014 from the Representative of the United States of America to the United Nations" (n. 28).

104. Ibid.

105. The killing by the IS of a few Canadian citizens does not reach the threshold of an armed attack.

106. "Letter dated 31 March 2015 from the Chargé d'affaires a.i. of the Permanent Mission of Canada to the United Nations addressed to the President of the Security Council" (n. 28).

107. The killing by the IS of a few British citizens does not reach the threshold of an armed attack.

108. Cameron, D. (2015), “Prime Minister's Response to the Foreign Affairs Select Committee's Second Report of Session 2015-16: The Extension of Offensive British Military Operations to Syria." http://www.parliament.uk/documents/commons-committees/foreign-affairs/PM-Response-to-FAC-Report-Extension-ofOffensive-British-Military-Operations-to-Syria.pdf [8 Dec. 2016]

109. "Letter dated 3 December 2015 from the Permanent Representative of the United Kingdom of Great Britain and Northern Ireland to the United Nations addressed to the President of the Security Council” (n. 32).

110. See supra chapter 2.1.

111. See supra chapter 2.2.

112. Germany and Belgium were reluctant to use the "unwilling or unable" test and preferred to rely on the fact that "IS occupied a certain part of Syrian territory" over which the government of Syria did not exercise effective control. "Letter dated 10 December 2015 from the Chargé d'affaires a.i. of the Permanent Mission of Germany to the United Nations addressed to the President of the Security Council" (n. 33); "Letter dated 7 June 2016 from the Permanent Representative of Belgium to the United Nations addressed to the President of the Security Council" (n. 12).

113. See supra chapter 3.

114. UNSC Res 2249 (20 November 2015) UN Doc S/2249/2015, para. 5.

115. Council of the EU, Outcome of the Council Meeting, 3426th Council Meeting, Foreign Affairs, Brussels, 14120/15, 16-17 November 2015, 6.

116. Bahrain, Qatar, Jordan, Saudi Arabia, and the United Arab Emirates.

117. See supra note 18 .

118. Black, I., and Roberts, D. (2014), "ISIS Air Strikes: Obama's Plan Condemned by Syria, Russia and Iran," Guardian, 12 September. https://www.the guardian.com/world/2014/sep/11/assad-moscow-tehran-condemn-obama-isis-airstrike-plan [8 Dec. 2016]; "Self-Defence? Moscow Questions France's Anti-ISIL Strikes," Sputnik International, 23 September 2015. https://sputniknews.com/ politics/20150927/1027618121/airstrikes-france-isil.html [8 Dec. 2016]

119. Saul, H. (2014), "Syria Air Strikes: Iran 'Says US Attacks on Isis Are Illegal,", The Independent, 23 September. http://www.independent.co.uk/news/ world/middle-east/syria-air-strikes-iran-says-us-attacks-on-isis-are-illegal-97512 45.html [8 Dec. 2016] 
120. Corten, O. (2016), “The 'Unwilling or Unable' Test: Has it Been, and Could it be, Accepted?," Leiden Journal of International Law 29(3): 12-13.

121. See for instance statements made by States following the adoption of UNSC 2249 (20 November 2015) in UNSC Verbatim Record (19 November 2014) UN Doc S/PV.7316.

122. Mendelson, M. (1996), "The Nature of the Subjective Element in Customary International Law," British Yearbook of International Law 66(1): 199.

123. ICJ, Military and Paramilitary Activities in and against Nicaragua (n. 44), para. 190; Report of the International Law Commission to the General Assembly, 18th Sess, May 4-July 19, 1966, GAOR 21st Sess, Supp No 9 (1966) in UN Doc A/6309/Rev.1, 77. See the definition of a peremptory norm of international law or a jus cogens norm in the Vienna Convention on the Law of Treaties (adopted 22 May 1969, entered into force 27 January 1980) Art. 53.

124. O'Connor, 2016 (n. 11): 94.

125. SC Res 1368 (12 September 2001) UN Doc S/1368/2001; SC Res 1373 (28 September 2001) UN Doc S/1373/2001.

126. 40 ILM (2001) 1267, 1268.

127. Ibid., 1270, 1273.

128. "Letter dated 7 October 2001 from the Chargé d'affaires a.i. of the Permanent Mission of the United Kingdom of Great Britain and Northern Ireland to the United Nations addressed to the President of the Security Council" (n. 88); "Letter dated 24 October 2001 from the Chargé d'affaires a.i. of the Permanent Mission of Canada to the United Nations addressed to the President of the Security Council" (24 October 2001) UN Doc S/2001/1005; "Letter dated 23 November 2001 from the Permanent Representative of France to the United Nations addressed to the President of the Security Council" (23 November 2001) UN Doc S/2001/1103; "Letter dated 23 November 2001 from the Permanent Representative of Australia to the United Nations addressed to the President of the Security Council" (23 November 2001) UN Doc S/2001/1104; "Letter dated 29 November 2001 from the Permanent Representative of Germany to the United Nations addressed to the President of the Security Council" (29 November 2001) UN Doc S/2001/1127; "Letter dated 6 December 2001 from the Permanent Representative of the Netherlands to the United Nations addressed to the President of the Security Council" (6 December 2001) UN Doc S/2001/1171; "Letter dated 17 December 2001 from the Permanent Representative of New Zealand to the United Nations addressed to the President of the Security Council" (18 December 2001) UN Doc S/2001/1193; "Letter dated 15 March 2002 from the Permanent Representative of Poland to the United Nations addressed to the President of the Security Council" (15 March 2002) UN Doc S/2002/275.

129. See for instance "Statement of the General Affairs Council of the European Union issued on 8 October 2001, on behalf of the European Union, on action against the Taliban following the terrorist attacks in the United States" (15 October 2001) UN Doc S/2001/967. 